\title{
A Comparative Study on T-beam Girder and Box Girder Bridges for Different Skew Angles
}

\author{
Ankush H. Patel and Spurti Mamadapur
}

\begin{abstract}
To cater the need of rapid urbanisation construction of bridges becomes the need of the time. It is often found that there is a need to change the layout of the bridge or to skew it by certain angle due to the presence of natural or man-made obstacles like river crosses, important structures, etc. Due to this it is often necessary to construct bridges with a certain skew angle. Skew angle can be defined as the angle subtended by the center line of the support and the global vertical direction. The response of the bridge structure depends on many factors like the cross-sectional parameters, span of the bridge, skew angle, type of live load, etc. In the current dissertation a study is carried out to understand the behavior of a two lane skew T-beam bridge and a skew box girder bridge for a fixed span of $20 \mathrm{~m}$ and skew angles of $10^{\circ}, 20^{\circ}, 30^{\circ}, 40^{\circ}, 50^{\circ}$ and $60^{\circ}$. The live load considered on the bridge are IRC Class AA Tracked and IRC Class A Train. Modeling and analysis of all the bridge models was performed in SAP2000 (Version 14) software after validating it with the values obtained by manual calculations. The analysis results for bending moment on girders/web, shear force on girder/web and bending moment on deck slab are obtained and compared with the results obtained for a normal bridge along with the comparison for different live loads.
\end{abstract}

Keywords--- Skew Angle, SAP2000, T-Beam, Box Girder, Dead Load, IRC Class AA Tracked and IRC Class A Train.

\section{INTRODUCTION}

\section{A. Bridge}

Bridge can be defined as an elevated structure above the A ground level for easy and comfortable flow of traffic. Bridges are usually provided to cross over any obstacles like flowing water, railway lines, important buildings, etc. Bridges are sometimes also provided for better connectivity in the city areas helping in providing emergency routes, medical aids. Depending on the type of load it carries brides are classified into Roadway bridges, Railway bridges, Pedestrian walks, etc. Roadway bridges are most widely used and studied as roadway is the most commonly used way of transportation.

\section{B. T-Beam Bridge}

A T-Beam bridge can be said to be a load bearing structure which resembles the shape of letter "T" in cross-section. T- beam sections are usually of reinforced cement concrete (RCC) structures or composite structure with steel longitudinal girders. However RCC longitudinal structure casted monolithically with RCC slabs are most widely used and advantageous. Transverse cross girders are also provided in the bridge section to resist transverse stresses in the bridge. The number of longitudinal and cross girders is usually decided based on the span and width of the bridge.

\section{Box Girder Bridge}

Box girder bridges are the bridges which resemble the shape of a box in the cross-sectional view. It usually has two vertical webs connected by two horizontal flanges at the top as well as at the bottom of the web. However in many designs intermediate webs are also sometimes provided to have a multi-cell type of box girder bridge. Box girders bridges are widely used today due to its various advantages over slab and beam type of bridges. Box girder bridges have found its wide spread importance in long span bridges. Box girder bridges are usually in the pre stressed concrete form for long span bridges. However, RCC box girder bridges are also being used for medium spans. Box girder bridges are preferred over slab and beam type of bridges as it provides better structural efficiency and stability, economy and pleasing appearance for long span bridges.

\section{Skew bridge}

A skew bridge is one whose longitudinal axis that is the direction of flow of traffic is not perpendicular to the axis of the support or abutment. The angle that the transverse axis of the bridge or the support makes with the vertical is known as a skew angle. The behavior of a skew bridge differs from that of a normal straight bridge due to the presence of the skew angle. In case of straight bridges the load distribution path is straight in two directions (General $\mathrm{X}$ and $\mathrm{Y}$ co-ordinate axis directions) whereas for a skewed bridge the load distribution takes the shortest possible paths between the two nearest supports ${ }^{[13]}$. Figure 1 shows the load distribution for normal and skewed bridges. 


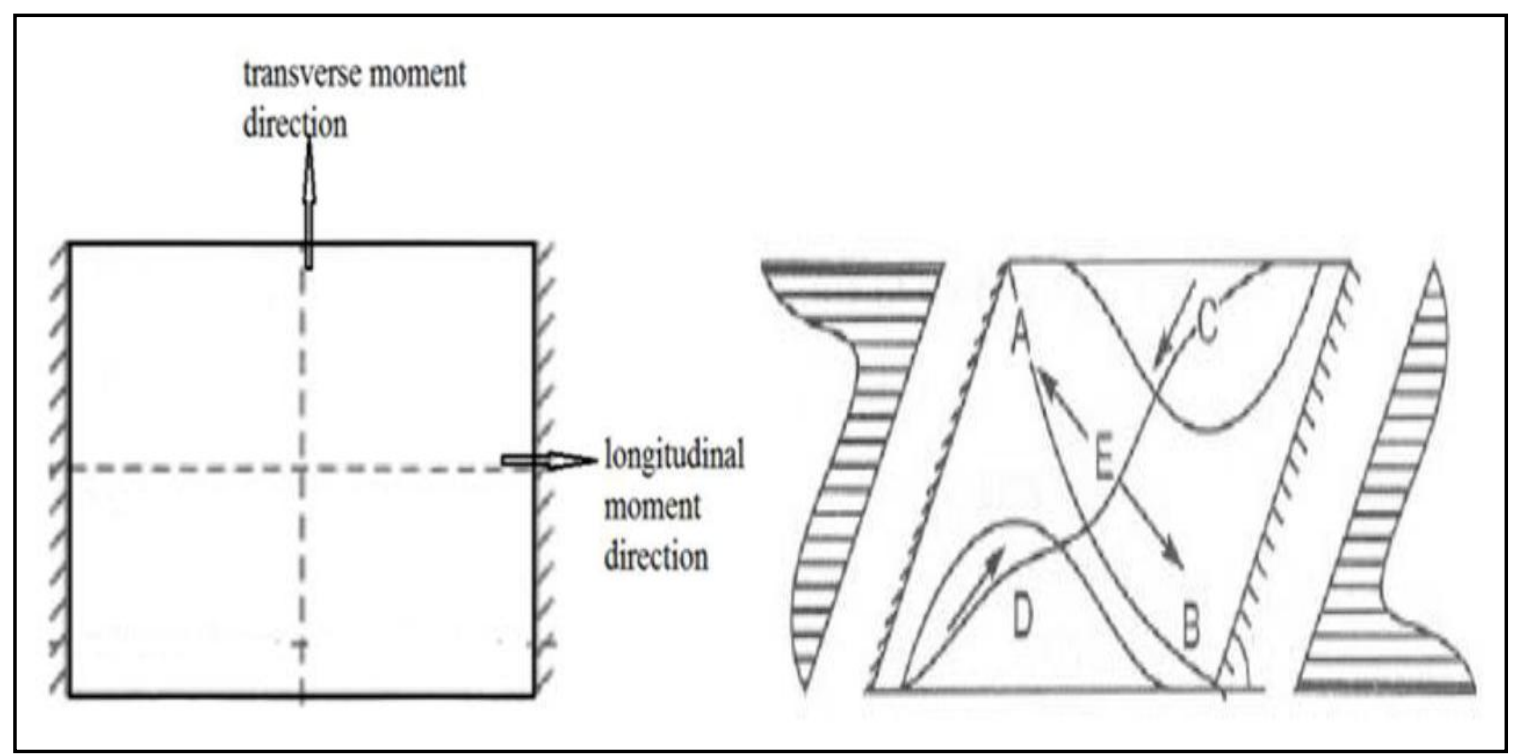

Figure 1: Load Distribution in a Bridge

\section{E. Objective}

The present study is carried out to study the behavior of Tbeam girder and box girder under different live loads conditions for different skew angles. The results so obtained are compared with that of normal bridge.

\section{MODELING}

\section{A. Finite Element Analysis}

Finite Element Method (F.E.M.) involves solving a complex problem by discretizing it into a number of elements known as finite elements. Finite elements are held together by nodes. The finite elements connected by nodes are assumed to possess two dimensional or three dimensional degrees of freedom according to the requirement of the designer. At first, when F.E.M. was introduced it was initially used just to solve two dimensional problems but ever since then the method has grown widely now to solve complex problems of structural analysis with an ease. F.E.M. today is being used to solve complex problems of civil, aeronautical and mechanical engineering. F.E.M. provides a complete tool for designing a problem, refine it and optimize the solutions obtained as per the requirement. Due to this advantage the importance and use of F.E.M. for the purpose of analyzing bridge model problems has increased considerably.

\section{Problem Definition}

Span

Carriage-way width

Overall Depth

Kerbs

Width of T-beam and cross beam

Depth of top slab

Thickness of wearing coat

$\mathrm{C} / \mathrm{C}$ distance of T-beam
$200 \mathrm{~mm}$

$80 \mathrm{~mm}$
$\mathrm{C} / \mathrm{C}$ distance of cross beam

Grade of concrete

$4 \mathrm{~m}$

Grade of steel

M25

Fe415

Live Load - IRC Class AA Tracked and A Train

Variation in skew angle

$0^{\circ}$ to $60^{\circ}$

Type of box girder

Single Cell

Width of web

$300 \mathrm{~mm}$

Depth of top slab

$200 \mathrm{~mm}$

Thickness of the bottom slab

$200 \mathrm{~mm}$

$\mathrm{C} / \mathrm{C}$ distance between the webs

$5.0 \mathrm{~m}$

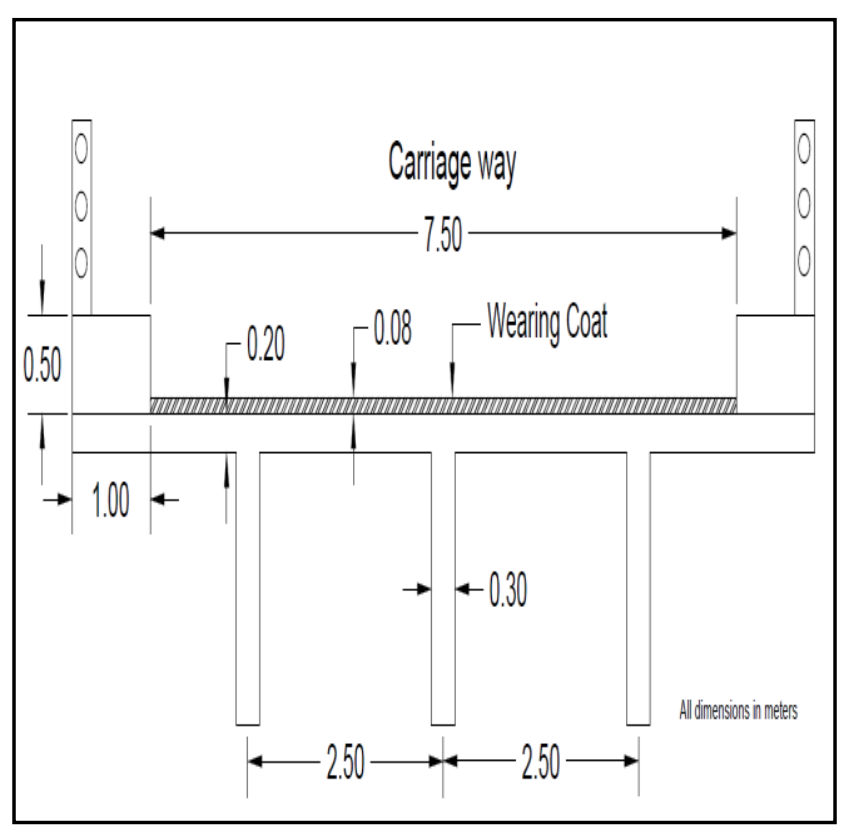

Figure 2: Cross Section of T-Beam Bridge 


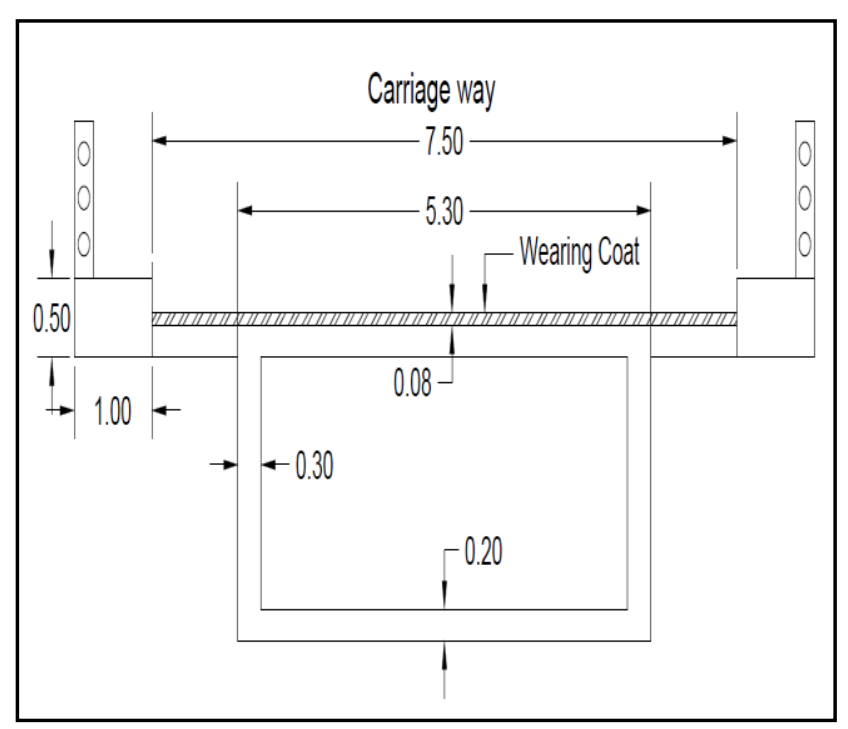

Figure 3: Cross Section of Box Girder Bridge

\section{B. List of Models}

In all 28 models are being modeled 14 each for T-beam girder and box girder bridge as follows

\begin{tabular}{|l|l|l|l|l|l|}
\hline No. & $\begin{array}{l}\text { Skew } \\
\text { angle }\left({ }^{\circ}\right)\end{array}$ & $\begin{array}{l}\text { Type of Live } \\
\text { load }\end{array}$ & No. & $\begin{array}{l}\text { Skew } \\
\text { angle }\left({ }^{\circ}\right)\end{array}$ & $\begin{array}{l}\text { Type of } \\
\text { Live load }\end{array}$ \\
\hline 1. & 0 & AA Tracked & 8. & 0 & A Train \\
\hline 2. & 10 & AA Tracked & 9. & 10 & A Train \\
\hline 3. & 20 & AA Tracked & 10. & 20 & A Train \\
\hline 4. & 30 & AA Tracked & 11. & 30 & A Train \\
\hline 5. & 40 & AA Tracked & 12. & 40 & A Train \\
\hline 6. & 50 & AA Tracked & 13. & 50 & A Train \\
\hline 7. & 60 & AA Tracked & 14. & 60 & A Train \\
\hline
\end{tabular}

C. Steps to Model in SAP2000

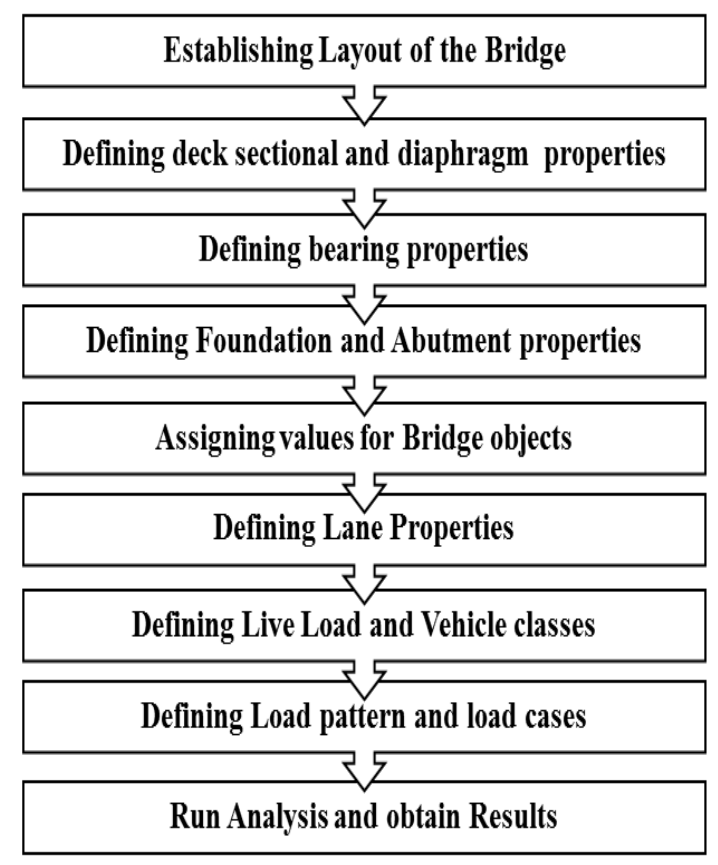

\section{RESULTS AND DISCUSSION}

The variations observed in all the models for bending moment, vertical shear force, torsion for the longitudinal girders and stresses in the deck slab are tabulated and discussed in the following sections. The results are tabulated for Dead Load + Live Load combination.

For T-beam

\section{Bending Moment}

\section{AA Tracked}

The maximum value of bending moment for the outer girder decreases along with the increase in the skew angle from $0^{\circ}$ to $60^{\circ}$. It is also observed that the point of maximum bending point shifts towards the first half of the span for $50^{\circ}$ and $60^{\circ}$ skew angles.

The maximum bending moment at the inner girder decreases with the increase in the skew angle up to a skew angle of $30^{\circ}$ and it increases from $40^{\circ}$ skew angle.

\section{A Train}

Bending moment for the outer girder decreases along with the increase in the skew angle. The percentage decrement for $60^{\circ}$ skew of the bridge is $12 \%$. It is observed that the point of maximum bending moment shift towards the first half for $60^{\circ}$ skew angle.

The maximum bending moment for the inner girder increases along with the increase in the skew angle. The percentage increase at $60^{\circ}$ skew angle is $6.57 \%$. The behavior of the point of maximum bending moment follows the similar pattern and shifts towards the first half of the span.

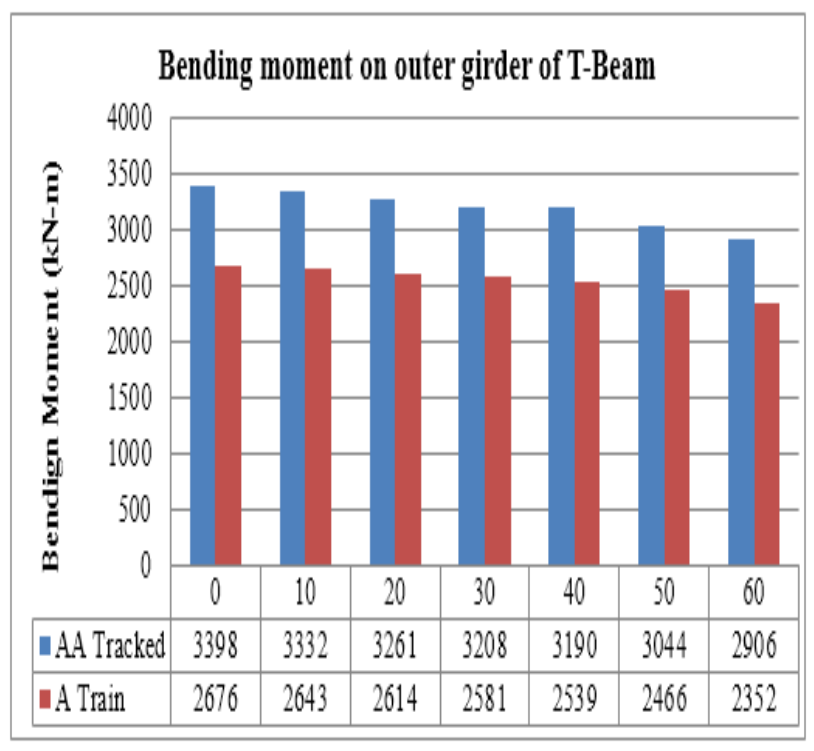

Figure 4: Bending Moment on Outer Girder for Different Skew Angles 


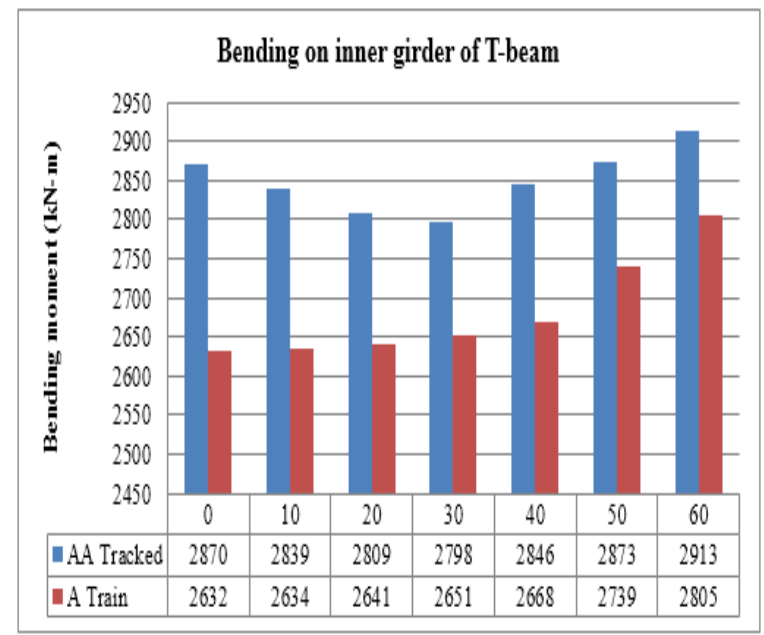

Figure 5: Bending Moment on Inner Girder for Different Skew Angles

\section{Shear Force}

\section{AA Tracked}

The maximum shear force on the girder decreases as skew angle increases from $0^{\circ}$ to $60^{\circ}$. The percentage decrease for $60^{\circ}$ skew is $30.39 \%$.

\section{A Train}

Shear force is maximum for a straight bridge and it decreases till the skew angle of $60^{\circ}$. The percentage decrement in the shear force value is $31.54 \%$.

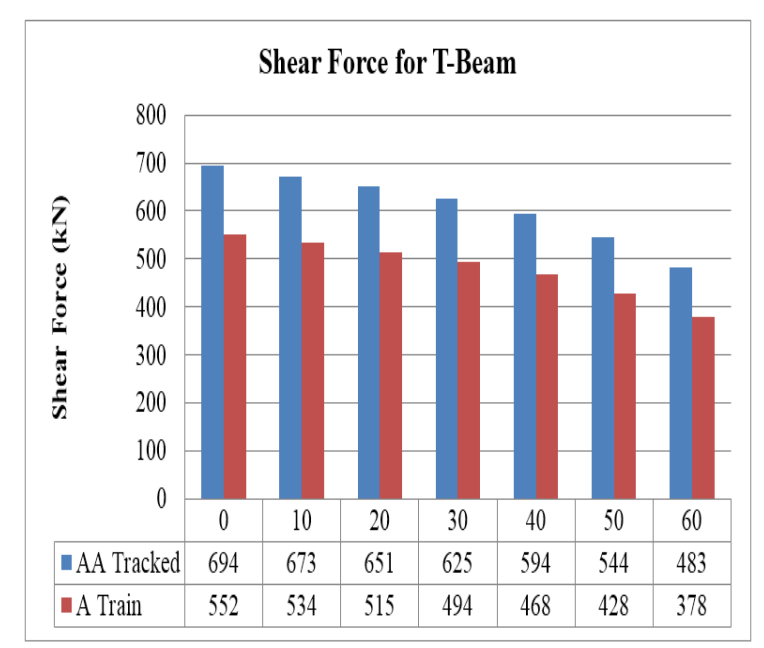

Figure 6: Shear Force of T-Beam for Different Skew Angles Deck Slab Moment

\section{AA Tracked}

The bending moment developed in the deck slab of the TBeam increases along with the increase in the skew angle. The bending moment is maximum for $60^{\circ}$ with an increase of $61.67 \%$.

\section{A Train}

Bending moment generated in the deck slab is minimum for a straight bridge. It increases by $68.07 \%$ to be maximum at $60^{\circ}$ skew angle.

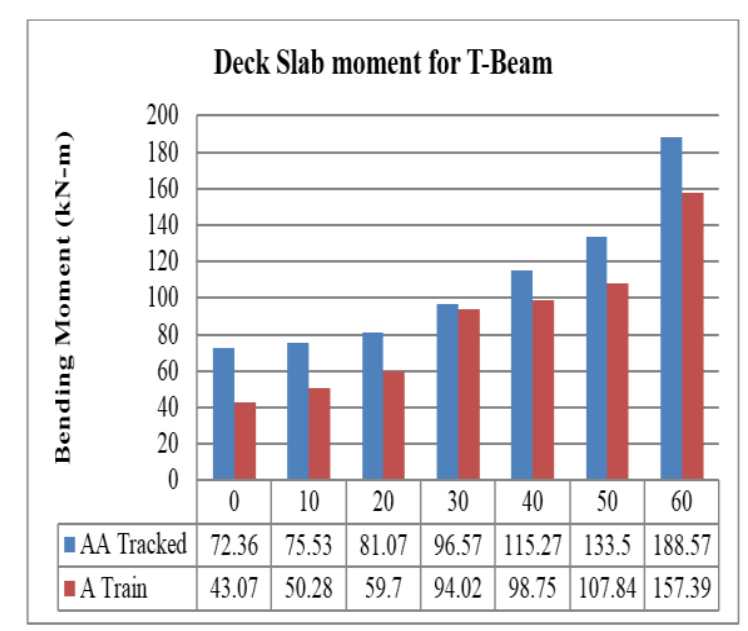

Figure 7: Deck Slab Moment of T-Beam for Different Skew Angles

\section{For Box Girder}

\section{Bending Moment}

\section{AA Tracked}

The bending moment generated in the web of the box girder decreases as the skew angle increases from $0^{\circ}$ to $60^{\circ}$. It is observed that the point of maximum bending moment shifts towards the first half of the span for the skew angles of $40^{\circ}$ and above.

\section{A Train}

Bending moment increases along with the increase in the skew angle. However the percentage increase is small. The maximum bending moment found at $60^{\circ}$ skew angle is $2.87 \%$ more than that for a straight bridge.

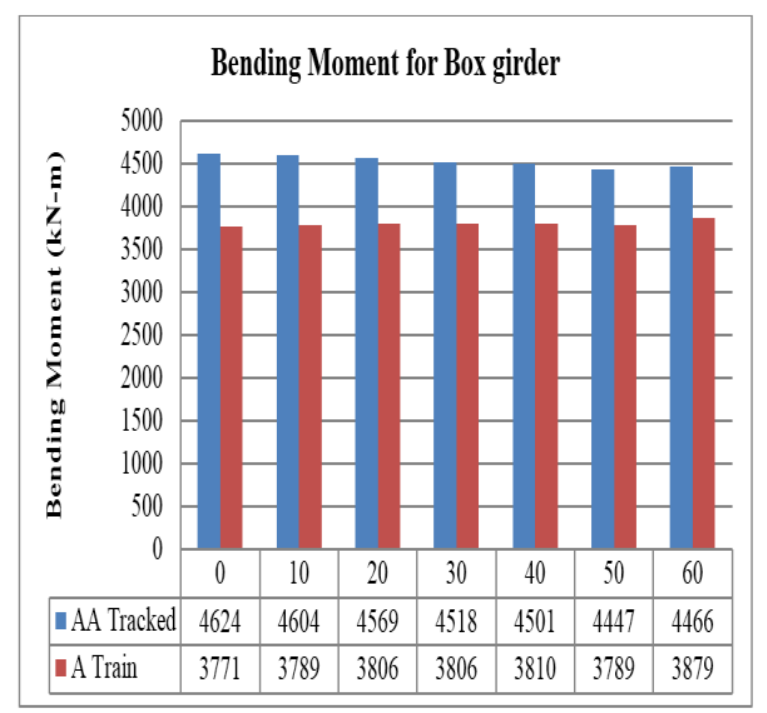

Figure 8: Bending Moment of Box Girder for Different Skew Angles 


\section{Shear Force}

\section{AA Tracked}

The shear force developed in the web decreases as the skew angle increases from $0^{\circ}$ to $60^{\circ}$. The percentage decrease in the shear force for $60^{\circ}$ skew is $24.87 \%$.

\section{A Train}

The shear force generated in the web of the girder is observed to decrease as the skew angle increases. The percentage decrement for $60^{\circ}$ skew angle is $28 \%$.

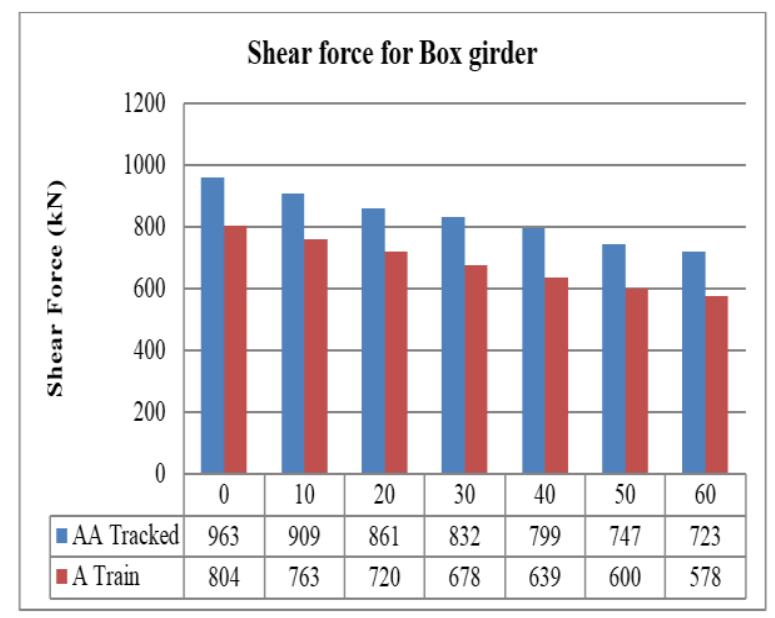

Figure 9: Shear Force of Box Girder for Different Skew Angles

\section{Deck Slab Moment}

\section{AA Tracked}

The bending moment developed in the slab of the girder decreases initially till $20^{\circ}$ with a percentage decrement at $20^{\circ}$ skew angle of $25.05 \%$. The bending moment generated in the slab increases rapidly for skew angles greater than $30^{\circ}$.

\section{A Train}

The bending moment generated in the deck slab of the bridge follows the same pattern as that of AA Tracked live load. It decreases by $4.70 \%$ at $20^{\circ}$ skew angle after which it increases by $61.61 \%$ for $60^{\circ}$ skew angle.

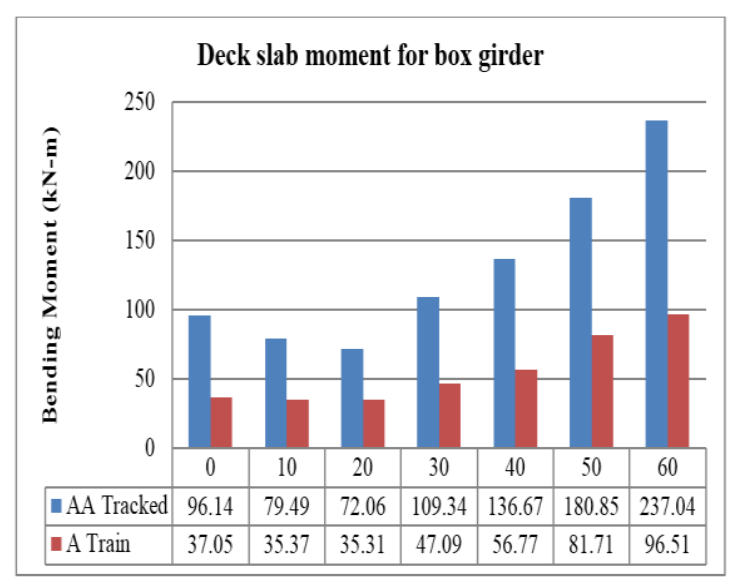

Figure 10: Deck Slab Moment of Box Girder for Different Skew Angles

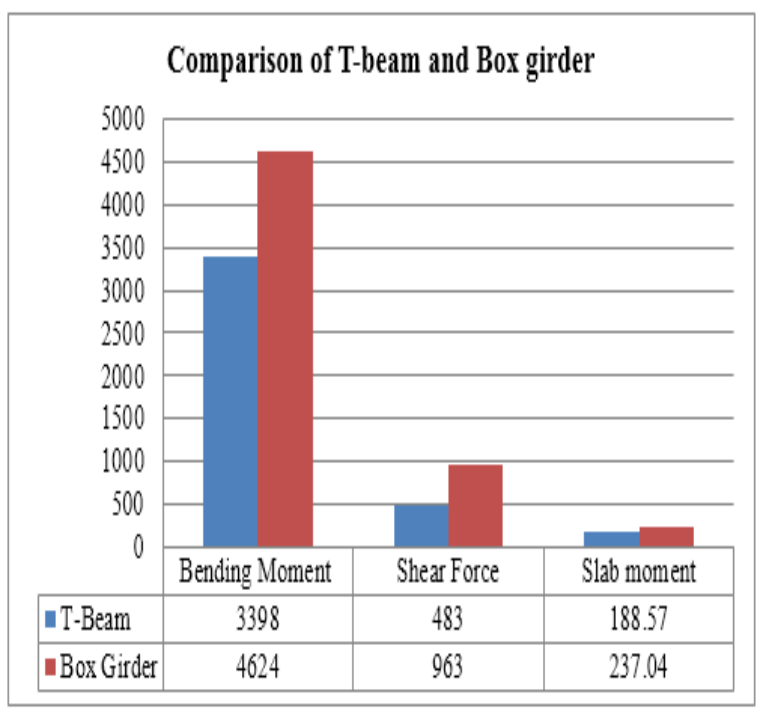

Figure 11: Comparison of T-Beam and Box Girder Bridge

\section{CONCLUSION}

In the present study comparison of various parameters like live load, skew angles and different cross-sections is carried out, the conclusions drawn from the work carried out are listed below.

1. The longitudinal bending moment on the obtuse angled girder of the T-beam decreases as the skew angle increases whereas for the inner girder it decreases till a skew angle of $30^{\circ}$ and it further increases till the skew angle of $60^{\circ}$. Similarly for the obtuse angled web of the box girder the bending moment decreases and it increases for the acute angled web. This is because the centerline of the bridge or the traffic flow is not parallel to the plane of maximum stress.

2. The shear force for both T-beam and box girder bridges decreases as the skew angle increases.

3. The deck slab moments generated also increases along with the increase in the skew angle due to wrapping of deck.

4. It is observed that the stresses generated by IRC Class AA Tracked vehicle are more compared to IRC Class A Train vehicle. Indicating that the bridges designed using IRC Class AA Tracked can be adopted for multipurpose use.

5. Comparing the results of longitudinal bending moment, shear force and torsional moment suggest that T-beam section is better than box girder section for medium span bridges.

6. SAP2000 software is useful in developing bridge models and providing comparable results. 


\section{REFERENCES}

\section{Published Papers}

[1] A. Chowgule and M. Manjunath, "Analysis of T-beam Skew Bridges", Indian Road Congress.

[2] Ansuman Kar et al., "Study on Effect of Skew angle in Skew Bridges", International Journal on Engineering Research and Development, Vol. 2, No. 12, Pp. 13-18, 2012.

[3] Arindham Dhar et al., "Effect of Skew Angle on Longitudinal Girder (support shear, moment, torsion) and Deck Slab of an IRC Skew Bridge", The Indian Concrete Journal, 2013.

[4] Dr.S.A. Halkude and Prof. C.Y. Akim., "Analysis of Straight and Skewed Box girder Bridge by Finite Strip Method", International Journal of Emerging Technology and Advanced Engineering, Vol. 2, No.11, 2012.

[5] A. Abdel-Mohti and G. Pekcan, "Seismic response of skewed RC boxgirder bridges. Earthquake Engineering and Engineering Vibration, Vol. 7, No. 4, Pp. 415-426, 2008.

[6] G. Fu and P.J. Chun, "Skewed Highway Bridges", Center for Advanced Bridge Engineering, 2013.

[7] T. Gupta and A. Misra, "Effect on support reactions of T-beam skew bridge decks. ARPN Journal of engineering and applied sciences, Vol. 2, No. 1, Pp. 01-08, 2007.

[8] I.S. Harba, "Effect of Skew Angle on Behaviour of Simply Supported RC T-Beam Bridge Decks", ARPN Journal of Engineering and Applied Sciences, Vol. 6, No. 8, Pp. 1-14, 2011.

[9] L.P. Gouda, "Study on Parametric Behaviour of Single Cell Box Girder under Different Radius of Curvatures", M.Tech. Dissertation report, 2013.

[10] I.G. Mallikarjun, et al., "Influence of Skew angle on Static behaviour of RCC and PSC Slab Bridge Decks", International Journal of Engineering Research and Advanced Technology, Vol. 1, No. 1, 2015.

[11] P. Reddy and S. Karuna, "Comparative Study on normal and Skew Bridge of PSC Box girder", International Journal of Research in Engineering and Technology, Vol. 4, No. 6, 2015.

[12] SAP, "User's Manual SAP 2000", Computers and Structures, Inc., Berkeley, California, U.S.A, 2000.

[13] B.V. Sindhu, et al., "Effect of Skew angle on static behaviour of Reinforced Concrete Slab bridge Decks", Internal Journal of Research in Engineering and Technology, IC-RICE conference issue, 2013.

[14] P.S. Sujith, et al., "Comparative study on T-Beam Skew Bridges", International Journal on Innovative in Research in Science, Engineering and Technology, Vol. 4, No. 9, 2015.

[15] V. Khatri, et al., "Analysis of Skew Bridges using Computational Methods", Internal Journal of Computational Engineering Research, Vol. 2, No. 3, Pp. 628-636, 2012.

\section{IRC Codes}

[16] IRC: 6-2014, "Standard Specifications and Code of Practice for Road Bridges", Section: II Loads and Stresses, Indian Roads Congress, November 2014

[17] IRC: 21-2000, "Standard Specifications and Code of Practice for Road Bridges", Section: III Cement Concrete (Plain and Reinforced), Indian Roads Congress, November 2000.

Text Book

[18] N. Krishna Raju, "Design of Bridges", Fourth Edition, Oxford and IBH Publishing Co. Pvt. Ltd., New Delhi. 